\title{
KONTRIBUSI MAJELIS ULAMA INDONESIA DALAM PROSES PEMBENTUKAN DAN IMPLEMENTASI UNDANG-UNDANG NOMOR 21 TAHUN 2008 TENTANG PERBANKAN SYARIAH
}

\author{
Faridatus Suhadak \\ Eko Priadi
}

\author{
Fakultas Syariah Universitas Islam Negeri (UIN) Maliki Malang \\ Jl. Gajayana No. 50 Malang \\ faridatus.suhadak@yahoo.com
}

Abstract

In response to the rapid development of Islamic economic, especially in Islamic banking, hence made Act Number 21 Year 2008 on Islamic Banking. Thus, the Act No. 21 year 2008 is a legal framework for the implementation of Islamic Banking in Indonesia. The enactment of Law No. 21 year 2008 is certainly can not be separated from the role of the Indonesian Ulama Council who have contributed substantially in supporting and patronizing Islamic Banking. This study is a normative research with qualitative approach that resulted the role of Indonesian Ulama Council in the formulation Act No. 21 year 2008. First, the involvement of National Shariah Council (DSN - MUI) in the assessment process, deepening and refinement of the substance of the formulation of Islamic Banking. Second, the recommendation and statement issued by the MUI related to the Act Number 21 Year 2008 on Islamic Banking. The MUI's role in the implementation of Act No. 21 year 2008 on Islamic Banking consists of two functions, i.e. regulatory functions are realized in the form of DSN-MUIfatwas related toIslamic Banking and control functions are realized in the form of DSN - MUI authority to recommend DPS in Islamic banks, give warning to non-compliant Islamic banks and propose to the authority to take action if the warning is ignored. This study recommends the need for effective coordination between the DSN - MUI with other stakeholders regarding fatwas/regulations produced to be implemented well.

Keywords: Indonesian Ulama Council, Islamic Banking and Islamic Legislation 
Jauh sebelum kedatangan kolonialis barat dengan misi Gold, Glory, dan Gospel-nya, sejarah telah mencatat bahwa syariah Islam sudah diterapkan dan mengatur kehidupan masyarakat nusantara di bawah pemerintahan kerajaan Islam yang terbentang dari Kesultanan Pasai di ujung barat hingga Kesultanan Ternate dan Tidore di ujung timur Indonesia. Namun tatanan syariah Islam ini mulai mengalami degradasi dan pelemahan ketika kolonialis barat mulai menguasai Indonesia. Dan proses pelemahan ini terus berlangsung hingga akhir masa kolonialisme barat di Indonesia.

Menjelang kemerdekaan Indonesia, para founding fathers juga berupaya untuk mengembalikan syariah Islam sebagai landasan kehidupan berbangsa dan bernegara. Namun upaya ini kandas di tengah jalan seiring dengan dihapuskannya tujuh kata dalam sila pertama Pancasila. Orde Lama dan Orde Baru telah berlalu tanpa adanya kemajuan yang berarti terhadap penerapan syariah Islam di Indonesia. Dan pasca reformasi, upaya untuk mengembalikan syariah Islam sebagai dasar negara kembali dilakukan oleh faksi Islamis di parlemen melalui usulan amandemen Pasal 29 UUD 1945 pada tahun 2000 silam.

Meski kembali mengalami kegagalan melalui amandemen konstitusi, namun agaknya demokratisasi Indonesia pasca reformasi ini justru memberikan angin segar bagi perkembangan proses tasyri' di tanah air. Sebab kini umat Islam dapat dengan bebas menyuarakan aspirasi mereka untuk melaksanakan nilai-nilai Islam dalam kehidupan berbangsa dan bernegara. Dan indikasi ini dapat dilihat dari berbagai peraturan perundang-undangan yang mengadopsi syariah Islam sebagai bahan pembentuk utamanya ataupun sebagai norma dan pertimbangan hukumnya. Hal ini mengindikasikan bahwa syariah Islam semakin mendapat penerimaan yang luas dalam tatanan hukum nasional meskipun tidak menjadi dasar negara.

Gencarnya proses legislasi syariah Islam ke dalam peraturan perundangundangan nasional ini tentu tak lepas dari peran serta para Ulama yang menjadi corong perjuangan umat Islam di Indonesia. Majelis Ulama Indonesia (MUI) sebagai representasi umat Islam Indonesia dan wadah persatuan Ulama, Zu'ama, dan Cendikiawan Muslim dari beragam latar belakang ormas dan spesifikasi keilmuan yang berbeda, sejak berdirinya pada 26 Juli 1975 hingga saat ini telah banyak berkiprah dalam mengawal perjalanan kehidupan umat Islam di Indonesia, terlebih lagi dalam upaya membumikan syariah Islam di tanah air.

Dalam dua dekade terakhir ini geliat ekonomi syariah di Indonesia mengalami perkembangan yang cukup pesat, khsususnya di bidang perbankan. Dimulai dengan didirikannya Bank Muamalat Indonesia sebagai bank pertama yang beroperasi berdasarkan syariah Islam pada awal tahun 1990-an, hingga saat ini perkembangan bank syariah mengalami pertumbuhan yang cukup signifikan. Hal ini ditandai dengan semakin banyaknya muncul bank syariah ataupun bank konvensional yang menjalankan unit usaha berbasiskan syariah. 
Seiring dengan semakin pesatnya perkembangan perbankan syariah di tanah air, maka kebutuhan akan adanya suatu regulasi khsusus yang mengatur kegiatan perbankan syariah menjadi suatu hal yang mendesak dan mutlak diperlukan. Untuk merespon hal ini, maka disahkanlah UU Nomor 21 Tahun 2008 tentang Perbankan Syariah yang menjadi payung hukum bagi pelaksanaan kegiatan perbankan syariah di Indonesia. Lahirnya UU Perbankan Syariah ini tentu tidak dapat dilepaskan dari peran serta Majelis Ulama Indonesia (MUI) yang memiliki andil cukup besar dalam membidani lahirnya bank syariah sejak awal dan terus mengawal perjalanan perbankan syariah hingga saat ini.

Berkaitan dengan latar belakang di atas, maka kajian ini akan fokus pada dua permasalahan. Pertama, bagaimana kontribusi MUI dalam proses perumusan dan pembentukan UU Nomor 21 Tahun 2008 tentang Perbankan Syariah. Kedua, bagaimana peran MUI melalui Dewan Syariah Nasional dalam implementasi UU Nomor 21 Tahun 2008 tentang Perbankan Syariah.

\section{METODE PENELITIAN}

Menentukan jenis penelitian sebelum melakukan riset merupakan hal yang sangat penting, sebab jenis penelitian merupakan payung yang akan digunakan sebagai landasan utama dalam pelaksanaan riset. Oleh karena itu maka penentuan jenis penelitian harus didasarkan pada pilihan yang tepat, sebab akan berimplikasi pada keseluruhan perjalanan riset.

Penelitian ini apabila dilihat dari sumber datanya yang berupa buku-buku atau karya tulis lainnya maka termasuk dalam penelitian yuridis normatif atau penelitian hukum doktrinal. Dalam penelitian jenis ini, hukum dikonsepkan sebagai apa yang tertulis dalam peraturan (law in books) atau sebagai kaidah yang merupakan patokan perilaku manusia yang dianggap pantas.

Sedangkan pendekatan yang digunakan dalam penelitian ini adalah pendekatan kualitatif. Menurut Lexy J. Moleong, penelitian kualitatif adalah penelitian yang bermaksud untuk memahami fenomena yang dialami oleh subjek penelitian misalnya perilaku, persepsi, motivasi, tindakan, dan lain-lain secara holistik, dengan cara mendeskripsikannya dalam bentuk kata-kata dan bahasa pada suatu konteks khusus yang ilmiah, dan dengan memanfaatkan berbagai metode ilmiah. Penelitian dengan pendekatan kualitatif menghasilkan data-data yang bersifat deskriptif. Sebab penelitian dengan pendekatan tersebut sangat kaya dan sarat dengan deskripsi.

Sementara itu, berdasarkan disiplin ilmu yang dipakai yaitu Tarikh Tasyri', pendekatan yang digunakan dalam penelitian ini adalah historis, analitis dan filosofis, karena tema yang diangkat berkisar pada Majelis Ulama Indonesia sebagai lembaga fatwa dan perannya dalam proses legislasi syariah Islam.

Dalam penelitian hukum selalu diawali dengan premis normatif, maka datanya diawali dengan data sekunder. Bagi penelitian normatif yang hanya mengenal data 
sekunder saja, jenis datanya adalah bahan hukum primer, bahan hukum sekunder dan bahan hukum tersier. Adapun metode pengumpulan data yang digunakan dalam penelitian ini adalah penelaahan naskah atau studi kepustakaan, yaitu dengan mengumpulkan data primer yang diambil dari buku-buku yang secara langsung membahas tentang permasalahan yang diteliti dan juga dari data-data sekunder yang secara tidak langsung membahas permasalahan yang diteliti namun relevan untuk dikutip sebagai pembanding.

Sedangkan metode analisis data yang digunakan dalam penelitian ini adalah metode content analisys (analisis isi). Content analisys merujuk kepada metode analisis yang integratif dan secara konseptual cenderung diarahkan untuk menemukan, mengidentifikasi, mengolah dan menganalisa dokumen untuk memahami makna, signifikasi dan relevansinya.

\section{Eksistensi Perbankan Syariah di Indonesia}

Sejarah perbankan syariah di Indonesia dimulai dengan berdirinya Bank Muamalat Indonesia (BMI) pada tahun 1992. Berdirinya BMI ini merupakan sebuah proses panjang dari keinginan kuat umat muslim Indonesia untuk memiliki bank yang bebas dari sistem ribawi. Berawal dengan dikeluarkannya Paket Kebijakan Oktober (Pakto) tahun 1988 oleh pemerintah tentang liberalisasi perbankan, yang memungkinkan perbankan untuk menetapkan suku bunga hingga nol persen. Hal ini menjadikan peluang untuk mewujudkan ide pendirian bank syariah semakin terbuka.

Maka berdasarkan rekomendasi dari Lokakarya Ulama tentang bunga bank di Cisarua Bogor tanggal 19-22 Agustus 1990 dan ditindaklanjuti melalui Musyawarah Nasional IV Majelis Ulama Indonesia di Jakarta tanggal 22-25 Agustus 1990, dibentuklah kelompok kerja untuk mendirikan bank syariah di Indonesia, hingga akhirnya berdirilah Bank Muamalat Indonesia (BMI) pada tanggal 22 April 1992. Pendirian BMI ini merupakan perintis bagi pertumbuhan perbankan syariah yang diharapkan akan berperan penting dalam membangun perekonomian nasional Indonesia, sehingga rekomendasi MUI untuk pendirian BMI mendapat dukungan penuh dari pemerintah dan partisipasi dari berbagai pihak.

Sebelum adanya undang-undang khusus yang mengatur tentang perbankan syariah, landasan operasional bank syariah berpayung pada UU Nomor 7 Tahun 1992 tentang Perbankan dan perubahannya dengan UU Nomor 10 Tahun 1998. Namun setelah disahkannya UU Nomor 21 Tahun 2008 tentang Perbankan Syariah, maka seluruh kegiatan operasional bank syariah berpayung kepada undang-undang ini.

Dalam UU Nomor 10 Tahun 1998 dijelaskan bahwa pengertian perbankan adalah segala sesuatu yang menyangkut tentang bank, mencakup kelembagaan, kegiatan usaha, serta cara dan proses dalam melaksanakan kegiatan usahanya. 
Sedangkan bank sendiri merupakan badan usaha yang menghimpun dana dari masyarakat dalam bentuk simpanan, dan kemudian menyalurkannya kepada masyarakat dalam bentuk kredit dan/atau bentuk lainnya dalam rangka meningkatkan taraf hidup rakyat.

Adapun definisi Perbankan Syariah sebagaimana dijelaskan dalam UU Nomor 21 Tahun 2008 adalah segala sesuatu yang yang menyangkut tentang Bank Syariah dan Unit Usaha Syariah, mencakup kelembagaan, kegiatan usaha, serta cara dan proses dalam melaksanakan kegiatan usahanya. Sedangkan Bank Syariah adalah bank yang menjalankan kegiatan usahanya berdasarkan prinsip syariah dan menurut jenisnya terdiri atas Bank Umum Syariah dan Bank Pembiayaan Rakyat Syariah.

Perbankan Syariah bertujuan untuk menunjang pelaksanaan pembangunan nasional dalam rangka meningkatkan keadilan, kebersamaan dan pemerataan kesejahteraan rakyat, dengan tetap berpegang pada prinsip-prinsip syariah secara menyeluruh ( $k a f f a h)$ dan konsisten (istiqomah). Di samping menjalankan fungsi menghimpun dan menyalurkan dana masyarakat, dalam UU Nomor 21 Tahun 2008 tentang Perbankan Syariah diatur ketentuan bahwa bank syariah juga dapat menjalankan fungsi sosial dalam bentuk lembaga baitul maal, yaitu menerima dana yang berasal dari zakat, infaq, shadaqah, hibah atau dana sosial lainnya dan menyalurkannya kepada organisasi pengelola zakat, serta menghimpun dana sosial yang berasal dari wakaf uang dan menyalurkannya kepada pengelola wakaf sesuai dengan kehendak pemberi wakaf.

UU Nomor 21 Tahun 2008 tentang Perbankan Syariah membedakan bank syariah menjadi dua jenis, yaitu: 1) Bank Umum Syariah, yaitu bank syariah yang dalam kegiatannya memberikan jasa dalam lalu lintas pembayaran, serta jasa-jasa perbankan lainnya. Dalam hal ini bank menerima dana simpanan dari masyarakat, kemudian mengalokasikannya kembali untuk memperoleh keuntungan; 2) Bank Pembiayaan Rakyat Syariah, yaitu bank syariah yang dalam kegiatannya tidak memberikan jasa dalam lalu lintas pembayaran. Selain dua jenis bank syariah di atas, ada juga Unit Usaha Syariah yang merupakan unit kerja dari kantor pusat bank umum konvensional yang berfungsi sebagai kantor induk dari kantor atau unit yang melaksanakan kegiatan usaha berdasarkan prinsip-prinsip syariah.

Sebagaimana lembaga perbankan pada umumnya yang menjalankan peran sebagai lembaga intermediasi keuangan antara unit ekonomi yang memiliki kelebihan dana dengan unit lainnya yang mengalami kekurangan dana, maka bank syariah juga melakukan kegiatan usaha berupa penghimpunan dana, penyaluran dana, serta menyediakan berbagai jasa transaksi keuangan kepada masyarakat. Semua kegiatan usaha bank syariah ini harus dilaksanakan dengan akad-akad yang didasarkan pada prinsip-prinsip syariah Islam. Dalam hal ini kesesuaian dengan prinsip-prinsip syariah Islam tersebut dibuktikan dengan adanya ketentuan dalam fatwa Dewan Syariah Nasional - Majelis Ulama Indonesia (DSN-MUI). 


\section{Fatwa Majelis Ulama Indonesia dan Legislasi Syariah Islam}

Majelis Ulama Indonesia (MUI) adalah majelis yang menghimpun dan menjadi wadah musyawarah para ulama, zu' ama dan cendekiawan muslim Indonesia untuk menyatukan gerak dan langkah umat dalam mewujudkan cita-cita bersama. MUI berdiri pada tanggal 7 Rajab 1395 H bertepatan dengan tanggal 26 Juli 1975 di Jakarta, sebagai hasil dari musyawarah para ulama, cendekiawan dan zu'ama yang datang dari berbagai penjuru tanah air, meliputi dua puluh enam orang ulama yang mewakili 26 Propinsi di Indonesia, 10 orang ulama yang merupakan unsur dari ormas-ormas Islam tingkat pusat, yaitu, Nahdhatul Ulama (NU), Muhammadiyah, Syarikat Islam (SI), Persatuan Tarbiyah Islamiyah (Perti), Al-Washliyah, Mathla'ul Anwar, Dewan Masjid Indonesia (DMI), Al-Ittihadiyyah, 4 orang ulama dari Dinas Rohani Islam, AD, AU, AL dan POLRI serta 13 orang tokoh/cendekiawan yang merupakan tokoh perorangan. Hasil musyawarah tersebut kemudian tertuang dalam "Piagam Berdirinya MUI" yang ditandatangani oleh seluruh peserta musyawarah yang kemudian disebut Musyawarah Nasional Ulama I.

MUI memiliki visi untuk menciptakan kondisi kehidupan kemasyarakatan, kebangsaan dan kenegaraan yang baik sebagai hasil penggalangan potensi dan partisipasi umat Islam melalui aktualisasi potensi ulama, zu'ama, aghniya', dan cendikiawan muslim untuk kemajuan dan kejayaan Islam dan kaum muslimin. Sedangkan misi MUI adalah menggerakkan kepemimpinan kelembagaan Islam secara efektif, sehingga mampu mengarahkan dan membina umat Islam dalam menjalankan syariat, serta menjadikan ulama sebagai panutan dalam mengembangkan akhlaqul karimah agar terwujud masyarakat khairu ummah.

Ada lima fungsi dan peran utama MUI sebagaimana telah dirumuskan dalam khittah pengabdian Majelis Ulama Indonesia, antara lain: 1) Sebagai pewaris tugastugas para Nabi; 2) Sebagai pemberi fatwa; 3) Sebagai pembimbing dan pelayan umat; 4) Sebagai gerakan perbaikan dan pembaruan; 5) Sebagai penegak amar ma'ruf dan nahi munkar.

Berkaitan dengan peran dan fungsi MUI sebagai pemberi fatwa, Muhammad Atho' Muzar menjelaskan bahwa sedikitnya ada empat jenis produk hukum Islam yang dicatat dalam perjalanan sejarah hukum Islam, yaitu kitab-kitab fiqih, keputusankeputusan pengadilan agama, peraturan perundang-undangan di negeri muslim dan fatwa-fatwa ulama atau mufti. Menurut Zamakhsyari, fatwa merupakan penjelasan hukum syara' tentang suatu masalah atas pertanyaan seseorang atau kelompok. Pendapat senada juga dikemukakan oleh Yusuf Qaradhawi yang mendefenisikan fatwa sebagai keterangan hukum syara' terhadap suatu persoalan sebagai jawaban atas pertanyaan yang diajukan oleh peminta fatwa, baik secara perorangan maupun kolektif. Dengan demikian dapat disimpulkan bahwa sebagai salah satu bentuk dari hukum Islam, fatwa berfungsi untuk memberikan jawaban dan solusi atas permasalahan yang dihadapi oleh umat Islam. Adapun pihak yang berwenang untuk 
memberi fatwa disebut mufti, sedangkan pihak yang meminta fatwa disebut mustafti.

Dalam struktur kepengurusan MUI ada dua elemen yang bertanggung jawab untuk mengeluarkan fatwa, yaitu Komisi Fatwa dan Dewan Syariah Nasional. Komisi Fatwa bertanggung jawab mengeluarkan fatwa yang berkaitan dengan bidang akidah dan aliran keagamaan, bidang ibadah, bidang sosial dan budaya, bidang pangan, obat-obatan, ilmu pengetahuan dan teknologi. Adapun Dewan Syariah Nasional bertanggung jawab untuk mengeluarkan fatwa dalam bidang ekonomi dan keuangan.

Ketika menetapkan suatu fatwa, MUI mengikuti pedoman atau panduan yang telah ditetapkan oleh Komisi Fatwa MUI. Berdasarkan Pedoman dan Prosedur Penetapan Fatwa MUI hasil Ijtima' Ulama Komisi Fatwa Se-Indonesia tanggal 16 Desember 2003, setiap fatwa yang ditetapkan oleh MUI harus didasarkan pada Al-Quran, Sunnah, Ijma', dan Qiyas, serta dalil-dalil yang mu'tabar. Setiap masalah yang telah jelas hukumnya di dalam nash, maka MUI menyampaikannya sebagaimana adanya yang tertera dalam nash tersebut.

Sedangkan terhadap masalah yang terjadi perbedaan (khilafiyah) di kalangan ulama madzhab, maka penetapan fatwa didasarkan pada hasil usaha penemuan titik temu diantara pendapat-pendapat ulama mazhab melalui metode al-jam'u wat taufiq. Jika usaha ini masih belum berhasil, maka penetapan fatwa didasarkan pada hasil tarjih melalui metode muqaranah dengan menggunakan kaidah-kaidah ushul figh muqaran. Adapun terhadap permasalahan yang tidak ditemukan pendapat hukumnya di kalangan mazhab, penetapan fatwa didasarkan pada hasil ijtihad jama'i melalui metode bayani, ta'lili (qiyasi, istihsani, ilhaqi), istishlahi, dan sadd al-dzari'ah. Di samping itu, penetapan fatwa juga harus senantiasa memperhatikan kemashlahatan umum (mashaalih 'ammah) dan tujuan-tujuan syariah (maqaashid al-syariah).

Keputusan fatwa MUI merupakan hasil sidang Komisi Fatwa MUI terhadap suatu permasalahan hukum yang telah disepakati oleh anggota Komisi Fatwa dan disahkan oleh pimpinan Komisi Fatwa MUI, baru kemudian ditetapkan dan ditandatangani oleh Dewan Pimpinan MUI, dan hal ini berlaku baik di tingkat pusat maupun daerah. Hasil keputusan tersebut dituangkan dalam bentuk Surat Keputusan Fatwa (SKF) yang dirumuskan dengan memuat uraian dan analisis permasalahan secara ringkas, dasar putusan dan sumber pengambilannya, serta disusun dengan bahasa yang mudah dipahami oleh masyarakat umum. Biasanya SKF disertai dengan rumusan tindak lanjut dan rekomendasi serta jalan keluar yang diperlukan sebagai konsekuensi dari SKF tersebut. Hal ini sesuai dengan sifat penetapan fatwa oleh MUI yang bersifat responsif, proaktif, dan antisipatif.

Ditinjau dari status kedudukannya, dapat dipahami bahwa eksistensi MUI adalah sebagai lembaga keagamaan yang berada di luar struktur ketatanegaraan, karena MUI tidak termasuk dalam bagian legislatif, eksekutif, ataupun yudikatif. Dengan 
demikian maka fatwa sebagai salah satu produk hukum Islam hasil ijtihad MUI sama sekali tidak mendapat tempat dalam hierarki tata urutan peraturan perundangundangan Indonesia. Pada pasal 7 ayat (1) UU Nomor 10 tahun 2004 tentang Pembentukan Peraturan Perundang-undangan, ditetapkan bahwa jenis dan hierarki peraturan perundang-undangan nasional terdiri atas UUD 1945, Undang-Undang/ Peraturan Pemerintah Penganti Undang-Undang, Peraturan Pemerintah, Peraturan Presiden, dan Peraturan Daerah.

Menurut KH. Ma'ruf Amin, ada dua hal yang terkait dengan sifat fatwa. Pertama, fatwa bersifat responsif, karena merupakan jawaban hukum yang dikeluarkan setelah adanya pertanyaan atau permintaan fatwa. Dan pada umumnya fatwa merupakan jawaban atas pertanyaan yang merupakan peristiwa/kasus yang telah terjadi atau nyata. Kedua, ditinjau dari segi kekuatan hukum, fatwa sebagai jawaban hukum tidaklah bersifat mengikat. Artinya orang yang meminta fatwa, baik perorangan, lembaga ataupun masyarakat luas, tidak harus mengikuti/mematuhi isi fatwa hukum yang diberikan padanya. Namun apabila fatwa tersebut kemudian diadopsi menjadi keputusan pengadilan ataupun hukum positif/regulasi di suatu wilayah tertentu, barulah fatwa memiliki kekuatan hukum yang mengikat.

Dari sini maka peran MUI menjadi penting. Sebab meskipun Indonesia tidak menjadikan syariah Islam sebagai dasar negaranya, namun bukan berarti mengesampingkannya. Syariah Islam tetap menjadi salah satu bahan pembentuk hukum nasional, serta merupakan norma dan pertimbangan hukum dalam pembentukan hukum nasional. Sehingga, ketika politik hukum nasional menghendaki suatu produk hukum yang mengakomodir syariah Islam, maka pemerintah ataupun lembaga legislatif dalam pembuatan regulasi tersebut harus mengacu kepada fatwa dari MUI selaku lembaga keagamaan yang kredibilitas dan otoritasnya dalam hal ini tidak diragukan lagi, karena para ulama yang terhimpun dalam MUI merupakan representasi dari seluruh elemen umat Islam di Indonesia dengan berbagai latar belakang dan disiplin ilmu yang berbeda.

Dalam proses pembentukan hukum nasional, fatwa MUI sebagai bagian dari produk hukum Islam, dapat berperan sebagai sumber hukum materiil yang menjadi esensi hukum ataupun sebagai landasan etika dan moralitas (filter) dari produk hukum tersebut. Hal ini bisa dilihat dari sekian banyak fatwa-fatwa yang dikeluarkan oleh MUI sejak berdirinya pada 1975 hingga saat ini, tidak sedikit diantaranya yang diserap dalam berbagai peraturan perundang-undangan, baik yang diadopsi secara utuh menjadi bagian integral dari hukum nasional, ataupun menjadi norma dan pertimbangan hukum dalam pembentukan hukum nasional.

Di samping itu, fatwa MUI juga dapat berperan sebagai sumber hukum formiil, dimana keyakinan hukum individu dan pendapat umum menjadi determinan formal yang membentuk hukum, dan menentukan berlakunya hukum. Karena fatwa sebagai pendapat hukum dari para ulama (ahli hukum Islam) dapat diposisikan sebagai doktrin atau pendapat ahli hukum. Sehingga jelaslah bahwa fatwa MUI sebagai 
salah satu bentuk hukum Islam dapat menjadi sumber pembentuk peraturan perundang-undangan.

\section{Dewan Syariah Nasional dan Sharia Compliance Perbankan Syariah}

Dewan Syariah Nasional (DSN) dibentuk oleh MUI pada 10 Februari 1999 sesuai dengan Surat Keputusan Majelis Ulama Indonesia Nomor: Kep-754/MUI/ II/1999. Dibentuknya DSN ini adalah untuk merespon perkembangan ekonomi syariah dan lembaga keuangan syariah yang semakin pesat, sehingga kebutuhan akan adanya suatu lembaga khusus yang menangani dan mengawal perjalanan ekonomi syariah di tanah air menjadi suatu hal yang mendesak dan mutlak diperlukan.

Secara struktural kelembagaan DSN berada di bawah MUI. Sehingga tugas DSN adalah menjalankan tugas MUI dalam menangani masalah-masalah yang berkaitan dengan ekonomi syariah, dan membantu pihak-pihak terkait seperti Kementerian Keuangan, Bank Indonesia dan instansi terkait lainnya dalam menyusun peraturan atau ketentuan untuk lembaga keuangan syariah. Disamping itu, pembentukan DSN juga dimaksudkan sebagai upaya untuk efisiensi dan koordinasi para ulama dalam merespon hal-hal yang berhubungan dengan masalah ekonomi dan keuangan. DSN diharapkan dapat berperan sebagai pengawas, pengarah dan pendorong penerapan nilai-nilai dan prinsip-prinsip syariah Islam di bidang perekonomian. Dengan demikian DSN harus berperan secara proaktif dalam menanggapi perkembangan masyarakat Indonesia yang dinamis di bidang ekonomi dan keuangan.

Berdasarkan Surat Keputusan MUI Nomor: Kep-754/MUI/II/1999 tentang Pembentukan DSN, tugas utama DSN adalah menggali, mengkaji, dan merumuskan nilai dan prinsip-prinsip syariah Islam dalam bentuk fatwa untuk dijadikan panduan dalam kegiatan dan urusan ekonomi pada umumnya dan khususnya terhadap kegiatan operasional serta produk dan jasa keuangan di lembaga keuangan syariah, sekaligus mengawasi pelaksanaan dan implementasi fatwa yang dikeluarkan oleh DSN.

Untuk dapat menjalankan tugasnya tersebut, maka DSN diberi kewenangan antara lain: 1) mengeluarkan fatwa yang mengikat Dewan Pengawas Syariah (DPS) di masing-masing lembaga keuangan syariah dan menjadi landasan bagi ketentuan/ peraturan yang dikeluarkan oleh instansi yang berwenang; 2) memberikan rekomendasi dan/atau mencabut rekomendasi anggota DPS pada suatu lembaga keuangan syariah;3) mengundang para ahli untuk menjelaskan suatu masalah yang diperlukan dalam pembahasan ekonomi syariah, termasuk otoritas moneter atau lembaga keuangan baik dari dalam maupun luar negeri; 4) memberi peringatan kepada lembaga keuangan syariah yang menyimpang dari fatwa yang telah dikeluarkan DSN; dan 5) mengusulkan kepada instansi yang berwenang untuk mengambil tindakan jika peringatan DSN tidak diindahkan. 
Pada dasarnya prinsip-prinsip perbankan syariah adalah merupakan bagian dari ajaran Islam yang berkaitan dengan bidang ekonomi dan keuangan. Oleh karena itu, diperlukan adanya standarisasi nilai-nilai syariah terhadap kegiatan operasional perbankan syariah. Dalam konteks inilah fatwa DSN-MUI berperan penting sebagai acuan bagi perbankan syariah dalam menjalankan kegiatan usahanya.

Dalam menetapkan fatwa, DSN-MUI mengacu kepada Pedoman dan Prosedur Penetapan Fatwa yang telah ditetapkan oleh Ijtima' Ulama Komisi Fatwa MUI se-Indonesia. Proses penyusunan fatwa DSN dimulai dengan tahap permohonan fatwa terkait permasalahan di bidang ekonomi dan keuangan dari masyarakat atau lembaga keuangan kepada DSN-MUI. Selanjutnya BPH akan membahas dan menyusun draft fatwa yang nantinya akan dibahas lebih lanjut dalam musyawarah pleno yang dihadiri oleh semua anggota DSN dengan melibatkan para praktisi/ pakar di bidang terkait, serta dihadiri oleh bank Indonesia atau lembaga keuangan lain yang terkait. Setelah draft fatwa tersebut dibahas dan mendapat persetujuan dalam musyawarah pleno DSN, maka draft fatwa itu akan ditetapkan menjadi Fatwa DSN-MUI dan ditanda-tangani oleh pimpinan DSN-MUI.

Pada proses selanjutnya, agar fatwa DSN-MUI memiliki kekuatan hukum yang mengikat, maka perlu diadopsi dan disahkan secara legal formal dalam bentuk peraturan perundang-undangan nasional. Maka dari itu, UU Nomor 21 Tahun 2008 tentang Perbankan Syariah mensyaratkan fatwa DSN-MUI sebagai salah satu dasar hukum yang harus dipatuhi oleh bank syariah. Karena secara teknis regulasi dan pengawasan bank syariah menjadi kewenangan Bank Indonesia selaku bank sentral, maka Fatwa DSN-MUI ini kemudian diserap ke dalam berbagai Peraturan Bank Indonesia dan regulasi lainnya yang berkaitan dengan kegiatan operasional bank syariah. Dengan demikian maka fatwa DSN menjadi bersifat mengikat karena diserap dalam peraturan perundang-undangan.

Untuk menjamin bahwa setiap kegiatan operasional perbankan syariah benarbenar djalankan sesuai dengan ketentuan syariah, yang dalam hal ini mengacu pada fatwa DSN-MUI, maka dibentuklah Dewan Pengawas Syariah (DPS). Ketentuan mengenai DPS ini diatur dalam Pasal 31 UU Nomor 21 Tahun 2008 tentang Perbankan Syariah yang menyatakan bahwa DPS wajib dibentuk di bank syariah dan bank konvensional yang memiliki unit usaha syariah. Selanjutnya dalam Pasal 109 UU Nomor 40 Tahun 2007 tentang Perseroan Terbatas dijelaskan pula bahwa Perseroan yang menjalankan kegiatan usaha berdasarkan prinsip syariah wajib memiliki DPS yang diangkat oleh RUPS atas rekomendasi Majelis Ulama Indonesia. Dengan demikian jelaslah bahwa DPS memiliki status hukum yang cukup kuat dalam peraturan perundang-undangan.

Dalam Keputusan DSN-MUI Nomor 3 Tahun 2000 tentang Petunjuk Pelaksanaan Penetapan Anggota DPS pada Lembaga Keuangan Syariah, dijelaskan bahwa DPS merupakan bagian dari lembaga keuangan syariah yang bersangkutan, yang penempatannya atas persetujuan DSN-MUI. Setiap lembaga keuangan syariah 
minimal harus memiliki tiga orang anggota DPS, yang berkedudukan di kantor pusat.

DPS sendiri pada hakikatnya merupakan lembaga independen yang beranggotakan para pakar/ahli di bidang fiqh muamalah atau lebih khususnya di bidang ekonomi dan keuangan syariah, yang berwenang untuk melakukan pengawasan secara langsung terhadap lembaga keuangan syariah agar tidak menyimpang dari ketentuan yang telah difatwakan oleh DSN-MUI. Dalam PBI No. 11/3/PBI/2009 tentang Bank Umum Syariah dijelaskan bahwa DPS bertugas memberikan nasehat dan saran kepada direksi serta mengawasi kegiatan bank agar sesuai dengan prinsip syariah.

Menurut Briston dan Ashker, ada tiga macam aktivitas DPS dalam melaksanakan pengawasan bank syariah. Pertama, Ex Ante Auditing, yaitu aktivitas pengawasan dengan melakukan pemeriksaan terhadap berbagai kebijakan yang diambil dengan cara melakukan review terhadap keputusan-keputusan dan seluruh jenis kontrak yang dibuat oleh manajemen bank syariah dengan semua pihak. Pemeriksaan ini bertujuan untuk mencegah bank syariah melakukan kontrak yang melanggar prinsip-prinsip syariah. Kedua, Ex Post Auditing, yaitu pengawasan dengan melakukan pemeriksaan terhadap laporan kegiatan (aktivitas) dan laporan keuangan bank syariah. Pemeriksaan ini bertujuan untuk menelusuri kegiatan dan sumbersumber keuangan bank syariah yang tidak sesuai dengan prinsip-prinsip syariah.

Ketiga, Perhitungan dan Pembayaran Zakat, yaitu memeriksa kebenaran bank syariah dalam menghitung zakat yang harus dikeluarkan dan memeriksa kebenaran dalam pembayaran zakat sesuai dengan ketentuan syariah. Pemeriksaan ini bertujuan untuk memastikan agar zakat atas segala usaha yang berkaitan dengan hasil usaha bank syariah telah dihitung dan dibayar secara benar oleh manajemen bank syariah.

Dengan demikian, dapat dipahami bahwa tujuan utama dari pengawasan yang dilakukan oleh DPS adalah untuk memastikan kepatuhan bank syariah terhadap prinsip-prinsip syariah (sharia compliance). Adapun kepatuhan bank syariah terhadap prinsip-prinsip syariah itu sendiri dapat dilihat dari beberapa indikator sebagai berikut, yaitu: 1) Akad atau kontrak yang digunakan untuk pengumpulan dan penyaluran dana sesuai dengan prinsip-prinsip syariah dan aturan yang berlaku; 2) Sumber dana berasal dari sumber dana yang sah dan halal menurut syariah; 3) Bisinis dan usaha yang dibiayai tidak bertentangan dengan syariah; 4) Dana zakat dihitung dan dibayar serta dikelola sesuai dengan aturan dan prinsip-prinsip syariah; 5) Seluruh transaksi dan aktivitas ekonomi dilaporkan secara wajar sesuai dengan standar akuntansi syariah yang berlaku; 6) Lingkungan kerja dan coporate culture sesuai dengan syariah. 


\section{Kontribusi Majelis Ulama Indonesia dalam Proses Pembentukan UU Nomor 21 Tahun 2008 tentang Perbankan Syariah}

Perkembangan perbankan syariah yang cukup pesat saat ini tentu tidak terlepas dari kontribusi MUI yang memainkan peran penting dalam membidani kelahiran dan mengawal perjalanan perbankan syariah di Indonesia hingga saat ini. Sehingga jika berbicara tentang kontribusi MUI dalam proses pembetukan UU Nomor 21 Tahun 2008 tentang Perbankan Syariah, pada hakikatnya hal ini merupakan akumulasi dari sebuah perjuangan panjang dalam upaya membumikan syariah Islam di bidang ekonomi dan keuangan, hingga akhirnya mencapai tahap legislasi syariah Islam kedalam sistem hukum nasional.

Sebagai wadah berhimpunnya para ulama, zu'ama, dan cendekiawan muslim yang menjadi representasi umat muslim Indonesia, MUI memiliki otoritas untuk mengeluarkan fatwa-fatwa keagamaan. Namun MUI bukanlah sebuah lembaga negara yang memiliki kewenangan untuk melaksanakan fungsi legislasi ataupun membuat sebuah regulasi yang memiliki kekuatan hukum untuk dilaksanakan dan dipatuhi oleh lembaga negara atau institusi pemerintahan lainnya. Sehingga dalam proses legislasi hukum Islam kedalam sistem hukum nasional, MUI berperan secara fungsional dalam membantu memberikan usulan, gagasan, dan pertimbangan yang berkaitan dengan hukum-hukum syariah kepada pemerintah, badan legislatif (DPR) dan stakeholder lainnya, serta menjadi penghubung dan penerjemah komunikasi yang menjembatani antara kepentingan pemerintah dengan umat muslim Indonesia.

Dalam konteks hukum perbankan syariah, UU Nomor 21 Tahun 2008 bukanlah undang-undang pertama yang mengatur tentang perbankan syariah. Sebelumnya regulasi mengenai perbankan syariah telah diatur dalam UU Nomor 10 Tahun 1998 tentang Perubahan atas UU Nomor 7 Tahun 1992 tentang Perbankan, juga dalam UU Nomor 4 Tahun 2007 tentang Perseroan Terbatas. Semua regulasi tentang perbankan syariah ini dalam proses perumusannya tentu tidak terlepas dari peran serta MUI, karena seluruh sistem operasional dan produk/jasa perbankan syariah harus memenuhi standarisasi syariah yang dalam hal ini dibuktikan dengan adanya ketentuan dari fatwa DSN-MUI.

Proses perumusan dan pembentukan UU Perbankan Syariah sendiri membutuhkan waktu yang tidak singkat, dimulai sejak diusulkan sebagai RUU Perbankan Syariah atas inisiatif DPR pada 13 September 2005, hingga akhirnya disahkan menjadi UU Nomor 21 Tahun 2008 tentang Perbankan Syariah pada tanggal 17 Juni 2008 dalam rapat paripurna DPR RI.

Adapun peran MUI dalam rangkaian proses perumusan dan pembentukan UU Nomor 21 Tahun 2008 sebagai payung hukum bagi penyelenggaraan perbankan syariah di Indonesia secara umum dapat dibedakan menjadi dua, yaitu peran secara langsung dan tidak langsung. Peran MUI secara langsung ini dapat dilihat dari keterlibatan DSN-MUI secara aktif dalam proses pengkajian, pendalaman serta 
penyempurnaan substansi dan rumusan RUU Perbankan Syariah dalam forum Rapat Dengar Pendapat Umum (RDPU) bersama Komisi XI DPR RI. Dalam hal ini keterlibatan DSN-MUI sangat penting untuk mengetahui substansi dan rumusan yang perlu disesuaikan dengan prinsip-prinsip hukum syariah dan muamalah.

Sedangkan peran secara tidak langsung MUI terlihat dari berbagai pernyataan sikap dan rekomendasi yang dikeluarkan oleh MUI. Hasil Ijtima' Ulama Komisi Fatwa Se-Indonesia II tahun 2006 dalam bidang masail qanuniyah (perundangundangan) merekomendasikan tiga hal berkaitan dengan RUU Perbankan Syariah yang ketika itu sedang dalam tahap pembahasan oleh DPR, yaitu: 1) Mendukung dan mendesak RUU Perbankan Syariah segera diundangkan; 2) Kewenangan menetapkan fatwa tetap dipegang oleh MUI melalui DSN-MUI; 3) Mempertahankan keberadaan DPS dalam setiap perbankan syariah.

Selanjutnya dengan disahkannya UU Nomor 21 tahun 2008 tentang Perbankan Syariah ini, maka kedudukan dan legitimasi sistem ekonomi syariah, khususnya di bidang perbankan, secara legal formal menjadi semakin kuat. Menyikapi hal ini, MUI berpendapat bahwa undang-undang ini harus segera ditindaklanjuti dengan tindakan konkrit. Maka melalui Ijtima' Ulama Komisi Fatwa MUI Se-Indonesia III tahun 2009, MUI merekomendasikan beberapa hal sebagai berikut:

1) Mendorong pemerintah untuk melakukan percepatan penetapan peraturan pelaksanaan UU Perbankan Syariah, baik dalam bentuk Peraturan Bank Indonesia (PBI) ataupun regulasi lainnya;

2) Pemerintah perlu segera melakukan akselerasi UU Perbankan Syariah dengan berbagai UU dan/atau peraturan terkait lainnya, seperti peraturan terkait masalah perpajakan terhadap sejumlah produk Lembaga Keuangan Syariah (LKS) dan Lembaga Bank Syariah (LBS);

3) Kepatuhan terhadap ketentuan syariah merupakan hal mutlak yang harus dilakukan oleh setiap LKS/LBS. Oleh karenanya, keberadaan, peran dan fungsi dari DPS sangatlah penting. Namun peran dan fungsi pengawasan DPS hingga saat ini masih dirasa sangat lemah dan kurang efektif. Keadaan seperti ini dapat menciderai kredibilitas dan citra LKS/LBS. Untuk itu, pemerintah bersamasama dengan MUI perlu membuat suatu sistem atau peraturan pengawasan dan ke-DPS-an yang lebih efektif dan fungsional;

4) Meminta pemerintah untuk lebih berpihak kepada pengembangan ekonomi syariah melalui pengadaan berbagai infrastruktur dan regulasi yang mendukung hal ini.

\section{Peran Majelis Ulama Indonesia dalam Implementasi UU Nomor 21 Tahun 2008 tentang Perbankan Syariah}

Dengan disahkannya UU Nomor 21 Tahun 2008 tentang Perbankan Syariah, kedudukan dan legalitas DSN-MUI secara legal formal menjadi semakin kuat. 
Menurut Yeni Salma Barlinti, dengan adanya legitimasi dan justifikasi dari undangundang ini, fatwa DSN-MUI sebagai legal opinion (pendapat hukum) dari para ulama telah masuk pada zona hukum positif yang mengikat secara hukum bagi seluruh pelaku ekonomi syariah. Dalam implementasi UU Nomor 21 Tahun 2008 tentang Perbankan Syariah ini, fungsi yang diperankan oleh DSN sebagai bagian dari struktur kelembagaan MUI setidaknya dapat dibedakan menjadi dua, yaitu fungsi regulasi dan fungsi kontrol.

Fungsi regulasi DSN-MUI terhadap perbankan syariah ini tercermin dalam ketentuan Pasal 26 UU Nomor 21 Tahun 2008 tentang Perbankan Syariah yang menyatakan bahwa seluruh kegiatan usaha serta produk dan jasa syariah wajib tunduk pada Prinsip Syariah yang difatwakan oleh Majelis Ulama Indonesia dan dituangkan dalam Peraturan Bank Indonesia (PBI) yang disusun oleh Komite Perbankan Syariah. Meskipun DSN tidak secara eksplisit disebutkan dalam undangundang ini, namun secara implisit dapat dipahami bahwa kewenangan untuk memberikan fatwa tentang ketentuan prinsip syariah itu dilaksanakan oleh DSN, karena secara struktural kelembagaan DSN merupakan bagian dari MUI.

Selanjutnya dari ketentuan Pasal 26 di atas juga dapat dipahami bahwa dalam menjalankan fungsi regulasi bagi perbankan syariah DSN-MUI tidak berdiri sendiri, namun memiliki keterkaitan dengan Bank Indonesia selaku bank sentral yang berwenang untuk membuat regulasi di bidang perbankan. Implikasinya, agar dapat menjadi regulasi bagi perbankan syariah fatwa DSN-MUI harus melalui mekanisme Peraturan Bank Indonesia. Untuk kepentingan tersebut, maka UU Perbankan Syariah juga mengamanatkan kepada Bank Indonesia untuk membentuk Komite Perbankan Syariah.

Selaku pihak regulator bagi lembaga perbankan, Bank Indonesia menggunakan fatwa DSN-MUI sebagai bahan referensi dalam penyusunan Peraturan Bank Indonesia (PBI) dan juga Surat Edaran Bank Indonsia (SEBI) yang bersifat eksternal. Dalam praktek pembuatan dan penyusunan regulasi yang berkaitan dengan perbankan syariah, Bank Indonesia hanya boleh merujuk kepada fatwa DSN-MUI, dan tidak merujuk pada fatwa yang dikeluarkan oleh institusi selain DSN-MUI.

Sejak dibentuk pada tahun 1999 hingga tahun 2011, DSN-MUI telah mengeluarkan sedikitnya 54 fatwa yang berkaitan dengan perbankan syariah. Dalam tataran praktis, peran DSN-MUI sebagai regulator bagi institusi perbankan syariah dibutuhkan dalam pengaturan beberapa hal sebagai berikut ini, antara lain: 1) Pembuatan dan/atau pengembangan produk baru, yang meliputi seluruh produk bank, baik asset, liabilities, dan services; 2) Produk diluar bank yang masih terikat dengan bank, seperti asuransi, pasar modal, pegadaian, serta instrument syariah; 3) Penghimpunan dana dan penyaluran pembiayaan; 4) Seluruh kegiatan operasional bank syariah.

Adapun fungsi kontrol DSN-MUI terhadap perbankan syariah tercermin dari ketentuan UU Nomor 21 Tahun 2008 yang mengatur tentang masalah kepatuhan 
syariah (sharia compliance) yang kewenangannya ada pada Majelis Ulama Indonesia yang kemudian direpresentasikan melalui Dewan Pengawas Syariah (DPS) yang harus dibentuk pada setiap Bank Syariah maupun bank konvensional yang memiliki Unit Usaha Syariah (UUS). Meskipun secara struktural DPS merupakan bagian dari bank syariah karena diangkat oleh Rapat Umum Pemegang Saham (RUPS), namun pada hakikatnya DPS merupakan perpanjangan tangan dari DSN-MUI dalam melaksanakan fungsi kontrol terhadap perbankan syariah.

DSN-MUI disamping bertugas untuk mengeluarkan fatwa yang berfungsi sebagai regulasi bagi perbankan syariah, juga berkewajiban untuk mengawasi/mengontrol penerapan fatwa yang telah dikeluarkan oleh DSN-MUI. Dalam menjalankan fungsi kontrol ini, DSN-MUI berwenang untuk: 1) Memberikan rekomendasi dan/atau mencabut rekomendasi nama-nama yang akan duduk sebagai DPS pada suatu bank syariah; 2) Memberikan peringatan kepada bank syariah untuk menghentikan penyimpangan dari fatwa yang telah dikeluarkan oleh DSN; 3) Mengusulkan kepada instansi yang berwenang untuk mengambil tindakan apabila peringatan DSN tidak diindahkan.

Fungsi kontrol DSN-MUI terhadap perbankan syariah juga terlihat dalam mekanisme kerja DSN-MUI yang mengharuskan DPS untuk menerbitkan laporan tahunan secara reguler disertai dengan pernyataan resmi bahwa bank syariah yang bersangkutan telah atau belum memenuhi ketentuan syariah sebagaimana tertuang dalam fatwa DSN-MUI, dan memberikan saran-saran pengembangan bank syariah kepada direksi/komisaris mengenai operasional bank syariah yang bersangkutan.

\section{KESIMPULAN DAN SARAN}

\section{Kesimpulan}

Lahirnya UU Nomor 21 tahun 2008 tentang Perbankan Syariah menunjukkan bahwa perjuangan untuk membumikan syariah Islam khususnya dalam bidang ekonomi dan keuangan, kini telah memasuki babak baru, dimana syariah Islam mendapat penerimaan yang luas dan legitimasi yang kuat dalam tatanan hukum nasional. Fatwa DSN-MUI yang pada dasarnya merupakan legal opinion dari para ulama yang bersifat tidak mengikat secara hukum, dengan adanya UU Nomor 21 tahun 2008 kini telah memasuki zona hukum positif yang memiliki kekuatan hukum dan mengikat bagi para pelaku ekonomi syariah, khususnya di bidang perbankan.

Peran MUI dalam proses perumusan dan pembentukan UU Nomor 21 tahun 2008 tentang Perbankan Syariah secara umum dapat dibedakan menjadi dua, yaitu peran secara langsung dan peran secara tidak langsung. Peran secara langsung ini dapat dilihat dari keterlibatan DSN-MUI secara aktif dalam proses pengkajian, pendalaman serta penyempurnaan substansi dan rumusan RUU Perbankan Syariah dalam forum Rapat Dengar Pendapat Umum (RDPU) bersama Komisi XI DPR 
RI. Sedangkan peran secara tidak langsung MUI terlihat dari berbagai rekomendasi dan pernyataan sikap resmi yang dikeluarkan oleh MUI secara kelembagaan berkaitan dengan UU Nomor 21 Tahun 2008 tentang Perbankan Syariah, diantaranya tertuang dalam Hasil Ijtima' Ulama Komisi Fatwa Se-Indonesia II tahun 2006 dan Hasil Ijtima' Ulama Komisi Fatwa Se-Indonesia III tahun 2009.

DSN-MUI dalam implementasi UU Nomor 21 Tahun 2008 tentang Perbankan Syariah menjalankan dua fungsi, yaitu fungsi regulasi dan fungsi kontrol. Fungsi regulasi ini diwujudkan dalam bentuk fatwa-fatwa yang dikeluarkan oleh DSNMUI yang berkaitan dengan perbankan syariah. Fatwa DSN-MUI dibutuhkan dalam pengaturan untuk pembuatan dan/atau pengembangan produk baru yang meliputi seluruh produk bank maupun produk diluar bank yang masih terikat dengan bank, penghimpunan dana dan penyaluran pembiayaan, serta seluruh kegiatan operasional bank syariah. Meskipun demikian, untuk dapat menjadi regulasi bagi perbankan syariah fatwa DSN-MUI harus terlebih dahulu diserap dan ditransformasikan kedalam bentuk Peraturan Bank Indonesia.

Adapun fungsi kontrol DSN-MUI terhadap perbankan syariah diwujudkan dalam bentuk kewenangan DSN-MUI untuk memberikan rekomendasi dan/atau mencabut rekomendasi nama-nama yang akan duduk sebagai DPS pada bank syariah, memberikan peringatan kepada bank syariah untuk menghentikan penyimpangan dari fatwa yang telah dikeluarkan oleh DSN, dan mengusulkan kepada institusi yang berwenang untuk mengambil tindakan apabila peringatan DSN tidak diindahkan. Di samping itu, DPS sebagai perpanjangan tangan DSN dalam melaksanakan fungsi kontrol terhadap bank syariah, bertugas untuk mengawasi secara langsung kegiatan usaha bank syariah agar sesuai dengan ketentuan dan prinsip syariah yang telah difatwakan oleh DSN-MUI.

\section{Saran}

Disarankan kepada DSN-MUI dan Bank Indonesia juga Lembaga Perbankan Syariah yang berkaitan untuk melakukan koordinasi yang lebih efektif dan intens dalam penyusunan fatwa DSN-MUI maupun regulasi lain yang berkaitan dengan Perbankan Syariah. Sehingga fatwa/regulasi tersebut dapat diimplementasikan dengan baik dan prinsip-prinsip syariah dalam kegiatan usaha perbankan tetap terjaga. Di samping itu, edukasi dan sosialisasi terkait peroduk dan jasa perbankan syariah kepada masyarakat luas juga perlu ditingkatkan dan dimassifkan. Sehingga kesadaran masyarakat untuk menggunakan jasa perbankan syariah dapat terbangun, dan perbankan syariah dapat berkembang lebih cepat.

\section{DAFTAR PUSTAKA}

Amin, M. 2005. Fatwa Dalam Sistem Hukum Islam. Jakarta: Elsas.

Amiruddin \& Zainal, A. 2006. Pengantar Metode Penelitian Hukum. Jakarta: Raja Grafindo Persada. 
Bisri, C.H. 1998. Hukum Islam dalam Tatanan Masyarakat Indonesia. Jakarta: Logos.

Bisri, C.H. 2004. Pilar-Pilar Penelitian Hukum Islam dan Pranata Sosial. Jakarta: Raja Grafindo Persada.

Bungin, B. 2007. Metodologi Penelitian Kualitatif; Aktualisasi Metodologis Ke Arah Ragam Varian Kontemporer. Jakarta: Raja Grafindo Persada.

Gayo, A.A. 2011. Laporan Akhir Penelitian Hukum Tentang Kedudukan Fatwa MUI dalam Upaya Mendorong Pelaksanaan Ekonomi Syariah. Jakarta: Badan Pembinaan Hukum Nasional Kementerian Hukum dan HAM RI.

Machmudin, D.D. 2003. Pengantar Ilmu Hukum; Sebuah Sketsa. Bandung: PT Refika Adhitama.

Majelis Ulama Indonesia. 2011. Himpunan Fatwa MUI Sejak 1975. Jakarta: Penerbit Erlangga.

Mudzhar, H.M. Atho', dkk. 2012. Fatwa Majelis Ulama Indonesia dalam Perspektif Hukum dan Undang-Undang. Jakarta: Puslitbang Kehidupan Keagamaan Kementerian Agama RI.

Nafis, M.C. 2011. Teori Hukum Ekonomi Syariah. Jakarta: UI Press.

Redaksi Sinar Grafika. 2009. Undang-Undang Perbankan Syariah 2008. Jakarta: Penerbit Sinar Grafika.

Shofa, B. 2004. Metode Penelitian Hukum. Jakarta: Rineka Cipta.

Sugiarto, A. 2008. Fatwa Majelis Ulama Indonesia Tentang Bunga Bank. Skripsi. Yogyakarta: UIN Sunan Kalijaga Yogyakarta.

Susamto, B. 2010. Aspek Hukum Lembaga Keuangan Syariah. Yogyakarta: Graha Ilmu.

Susamto, B. 2010. Hukum Perbankan Syariah di Indonesia. Yogyakarta: UII Press.

Sutedi, A. 2009. Perbankan Syariah Tinjauan dan Beberapa Segi Hukum. Jakarta: Penerbit Ghalia Indonesia.

Undang-Undang Nomor 10 Tahun 1998 tentang Perubahan Undang-Undang Nomor 7 Tahun 1992 tentang Perbankan.

Undang-Undang Nomor 40 Tahun 2007 tentang Perseroan Terbatas.

Undang-Undang Nomor 21 Tahun 2008 tentang Perbankan Syariah.

PBI No. 11/3/PBI/2009 tentang Bank Umum Syariah.

Harry, A.A. Catatan Perkembangan Pembahasan RUU Perbankan Syariah, sumber: http:// hharryazharazis.com/detail/886/artikel/22/detail/79/catatan-perkembanganpembahasan-ruu-perbankan-syariah-dpr-ri.cnet, diakses pada tanggal 14 November 2013.

Majelis Ulama Indonesia, Profil Majelis Ulama Indonesia, sumber: http://www.mui.or.id, diakses pada tanggal 16 Juni 2013.

Rahayu, H. Kedudukan Fatwa MUI Pasca Amandemen UU Peradilan Agama, sumber: http://gagasanhukum.wordpress.com, diakses pada tanggal 18 Juni 2013. 